\title{
Development of Regional Excellence Potentials Through Food Diversification Based on Local Resources
}

\author{
Andi Abriana ${ }^{1, *}$, Erni Indrawati ${ }^{2}$, Rahmawati Rahman $^{3}$ \\ ${ }^{1}$ Food Technology, Bosowa University Makassar, Indonesia \\ ${ }^{2}$ Aquaculture, Bosowa University Makassar, Indoensia \\ ${ }^{3}$ City and Regional Planning, Bosowa University Makassar, Indonesia \\ *Corresponding author. Email: andi.abriana510@gmail.com
}

\begin{abstract}
Maros is one of the districts in the South Sulawesi Province which is the center of fisheries business development. Maros Regency as a coastal and marine area has the potential to develop land and sea fisheries that are quite large with the largest production of fishery products in ponds as a local resource that is a type of milkfish. Milkfish from Maros Regency is an excellent product that is well known and sought after by the public both local consumers and from various regions because it has a good taste. Milkfish are mostly served in the processed form with various kinds of processed products. Diversification of processed milkfish products begins with removing the thorns that are very much found throughout the body of milkfish which is quite troublesome if consumed especially on small milkfish, namely by applying the technology of pulling thorns to produce fresh milkfish without disturbing thorns. Fresh fish without thorns is ready to be processed into various products, namely shredded milkfish products and milkfish meatballs. The products of milkfish are extracted from thorns, shredded milkfish and milkfish meatballs packed in vacuum packaging so that they can last longer and can be used as regional excellence products from Maros Regency.
\end{abstract}

Keywords: milkfish, milkfish extract thorns, shredded milkfish, milkfish meatballs

\section{INTRODUCTION}

Indonesia has a large potential of fisheries resources, both marine and inland fisheries [9]. The fisheries sector is a part of renewable natural resources. However, this does not mean that renewable natural resources will continue to have resulted if there is no sustainable and sustainable management [8].

Maros Regency of South Sulawesi Province is one of the districts in the South Sulawesi region which is the center of fisheries business development. Maros Regency as a coastal and marine area has considerable potential for developing land and sea fisheries. The largest number of pond fisheries production cultivated, especially in areas that have the potential for cultivation, is milkfish with the largest production reaching 1,254.01 tons.

Milkfish (Chanos chanos) is a popular food fish in Southeast Asia. This fish is the only species that still exist in the Chanidae tribe [4]. Milkfish is a type of fish that is very popular with the community because it has good nutrient content, namely high protein content. Fish protein is needed by humans because in addition to being more easily digested it also contains amino acids with a pattern that is almost the same as the pattern of amino acids contained in the human body [3]. Milkfish has a very high nutrient content and is very beneficial for the body. The nutritional content of milkfish is that it contains energy of
129 kilocalories; 20-gram protein; 0-gram carbohydrates; 4.8 grams of fat; 20 milligrams of calcium; 150 milligrams of phosphorus; and 2 milligrams of iron. Besides that, there are $150 \mathrm{IU}$ in milkfish which is also contained in vitamin A; vitamin B1 0.05 milligrams; and vitamin C 0 milligrams and parts of milkfish that can be consumed as much as $80 \%$ [2]. Milkfish is one of the favorite fish because it has an excellent taste when cooked with the right spices. Milkfish are mostly served in the processed form with various kinds of processed products. One of them is processed into a thorn pulling milkfish which can be further processed into various types of foods such as presto milkfish, shredded fish, fish meatballs and so on [5]. Although it has a specific taste and is much popular, milkfish have many weaknesses in thorns that are spread throughout the flesh.

Milkfish commodities in Maros Regency are superior products that are well known and are in demand by the public both local consumers and from various regions. Milkfish is very abundant but maximum processing has not been done to increase its selling value. The main disadvantage of milkfish is that its thorns are very numerous and the small spines found throughout the body of milkfish are quite troublesome especially in small milkfish. In addition, the damage caused by the decay process in milkfish is felt to greatly hamper the milkfish marketing business and cause huge losses for milkfish farmers who are partners in this service activity. Therefore, 
efforts need to be made to overcome the main weaknesses of milkfish, namely by removing the thorns that are very much found throughout the body of milkfish by applying the thorn pull technology. The technology of pulling thorns produces fresh milkfish without disturbing thorns. Fresh fish without thorns is ready to be processed into shredded milkfish products and milkfish meatballs which can be used as a delicious and nutritious meal; and ready to be used as a superior product from Maros Regency.

\section{METHODS}

The diversification of processed milkfish products extracting thorns into shredded milkfish products and milkfish meatballs, is an effort to be able to further increase milkfish production which indirectly will also increase profits from the sale of various types of products produced.

The method of approach and application of science and technology that has been applied to solve the problem of milkfish, namely the method of extension, training and practice and mentoring approaches. Methods of counseling, training and practice and mentoring approaches are carried out with the following steps:

Participatory Extension is learning activities about things that are the main problem for SMEs. This method takes the form of a meeting with a combination of lectures and discussions at the SME group level.

Training includes demonstration activities and practice activities of members in groups. In the demonstration activity, the implementing team will invite several experts (experts) related to providing knowledge about specific matters.

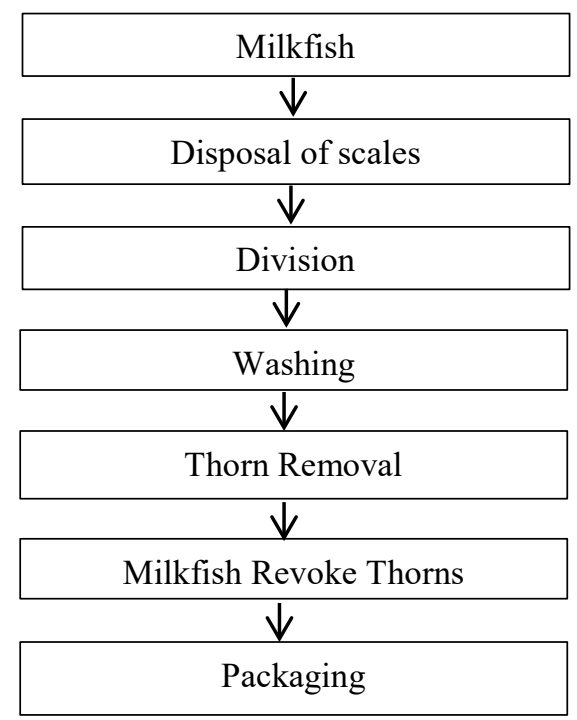

Figure 1. Flow Chart of Spiny Milkfish Processing

Mentoring is carried out with an institutional approach, namely a continuous mentoring process throughout the activity. The implementation of this assistance was focused on guidance and mentoring of SME groups to produce processed products of milkfish pulling thorns, namely shredded milkfish and quality milkfish meatballs.

The methods for processing milkfish, shredded milkfish and milkfish meatballs are as follows: (1) Processing of milkfish extracts of thorns (Figure 1); (2) Processing of shredded milkfish (Figure 2); and (3) Processing of milkfish meatballs (Figure 3) [1].

\section{RESULTS AND DISCUSSION}

Processing of Milkfish Extract Thorns

Milkfish extraction is done by using fresh milkfish obtained from the pond. Milkfish is cleaned by removing the contents of the stomach and removing the scales. After cleaning, then the milkfish is cut in half and then the extraction of thorns is done by first making the extraction path which consists of four lines, namely two lanes on the left side and two lanes on the right side. Revocation of thorns is done by using tweezers made of stainless steel (stainless steel). Revocation of thorns is done carefully so that all thorns can be removed and the milkfish is not damaged. After extracting all the thorns on the milkfish, the difference will be clearly seen with the milkfish which is not extracted from thorns. After the spines are removed all the milkfish pull the thorns ready to be packed. In order to have a longer-lasting power, the milkfish pull out the thorns as soon as possible to do the packaging and then cool it down by storing it in the freezer. To keep the milkfish from pulling thorns not easily damaged, vacuum packaging is carried out.

The packaging tool used is a vacuum packaging brand "Maksipack" The activity of removing the thorns from one fish is initially lasting for 15 minutes; so that it can only be completed 3-4 fish per hour. After being skilled, pulling thorns for one milkfish can be completed in 10 minutes, so that within 1 hour, the removal of 5-6 milkfish can be completed.

The advantages of thorn milkfish business can be calculated based on the price of the milkfish purchased for farmer farmers for Rp. $20,000 / \mathrm{kg}$, so after removing the milkfish the spines are sold at Rp. 60,000/ kg. These thorny fish are selling well. Consumers expressed satisfaction in buying milkfish pulling thorns because the thorns that had been removed were not too disturbing when consumed. In addition, the flavor of milkfish from Maros Regency has the advantage of being very tasty and tasty, different from the taste of milkfish from other regions. The method of pricing is done by considering various factors as follows: fresh milkfish prices and production costs, namely wages to revoke milkfish spines and packaging costs. If specified, the cost of producing milkfish pulls the quills per $\mathrm{kg}$ as follows: the price of fresh milkfish Rp. 20,000 -/kg; wages for revocation of 1 $\mathrm{kg}$ is Rp. 20,000,- and the cost of packaging is Rp. 11,000, $-/ \mathrm{kg}$. The total cost of producing milkfish pulls the thorn Rp. 51,000, - $/ \mathrm{kg}$. Taking into account the production 
costs, the price per kilo of milkfish can be determined to be set at Rp. 60,000. With this implementation, Tegar Mandiri UKM experienced an increase in production and sales by $15 \%$ from before. If a worker can pull out milkfish spines for 10 minutes per tail, then for one hour can be completed 5-6 milkfish pull out thorns. If a worker works for five hours from 09.00-14.00 WITA with wages to revoke a thorn of Rp. $20,000 / \mathrm{kg}$ can get a minimum income of IDR 100,000-150,000 for part time / half day.

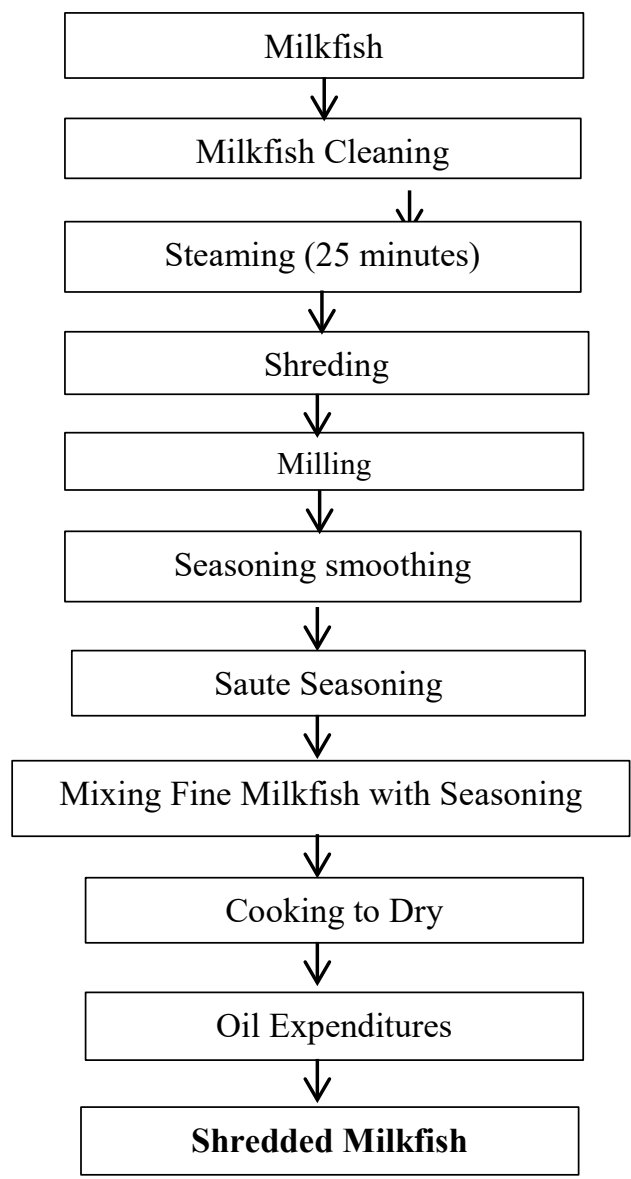

Figure 2. Flow Chart of Shredded Milkfish Processing

\section{Processing of Shredded Milkfish}

The processing of shredded milkfish is done by using raw milk extract raw material, so it is no longer a hassle to get rid of milkfish spines. Shredded milkfish processing is a form of food diversification activities using local resources, namely milkfish. The main strategies used in utilizing technology to diversify products from various alternative development strategies for the use of technology are solutions for the diversification of products so that business groups can survive against competitors, meet consumer demand and are expected to be able to implement scale based priority according to needs, development, competition and have measurable targets in developing abon fish processing business [7].
Results of research conducted [10]; concluded that the marketing description of shredded fish was specified in abon fish marketing management which began from planning by observing the situation based on demand from consumers, the implementation carried out by group members that directly to the location of consumers, control carried out to find out if there were deviations and causes, and evaluation of implementing marketing of abon ikan; while according to [6], that the abon ikan business can be developed because it provides a large profit with the following results: at an interest rate of $12 \%$ abon fish business is feasible to be developed with an NPV value of Rp. 3,700,383; IRR 29.61\% (greater than the value of the loan interest used 12\%); Net B / C 1.02; ROI of $20.79 \%$ and Break Event Point (BEP) of 435 units /year.

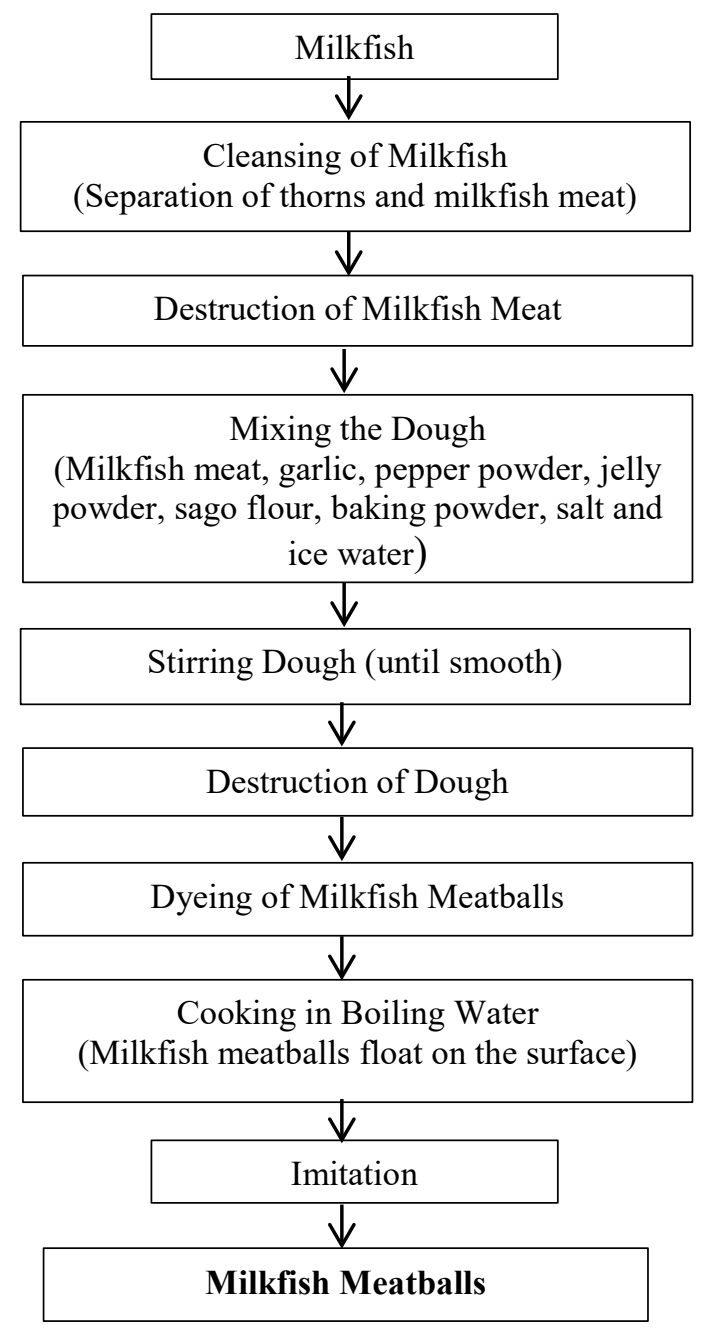

Figure 3. Flow Chart of Milkfish Meatball Processing 

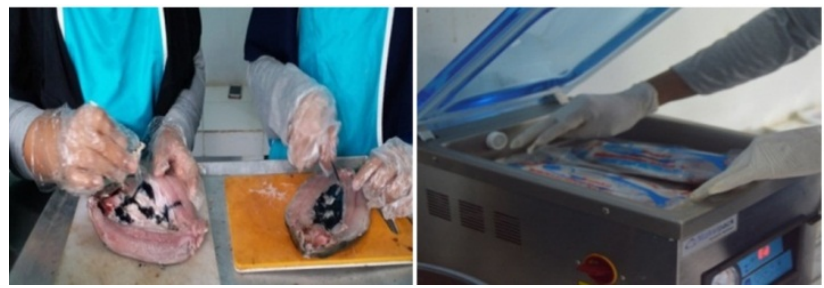

Figure 4. The process of extracting milkfish spines

Figure 5. The thorny milkfish vacuum packaging process

\section{Processing of Milkfish Meatballs}

The products of milkfish meatballs produced are quite good with the distinctive taste of milkfish and the color of fish meatballs which are quite interesting because they are whitish. When viewed from the appearance of milkfish meatballs, then at a glance it is no different from meat meatballs with distinctive color from meat; but later if it is consumed then there is a difference between the taste of the milkfish. Products of milkfish meatballs are traded in the form of plastic packaging; in packs per $1 \mathrm{~kg}$ of milkfish meatballs with the packaging price of $\mathrm{Rp}$. 70,000 ,-

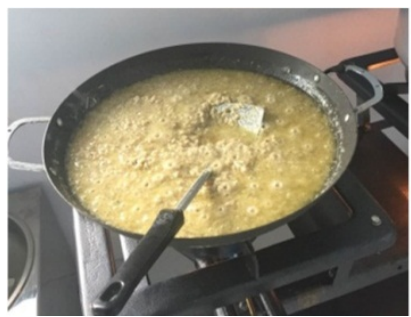

Figure 6. Shredded cooking process

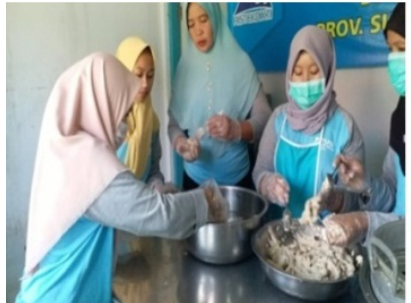

Figure 8. Milkfish meatball processing

\section{CONCLUSION}

Milkfish products pull the thorns produced with the appearance that is quite good and the color that is not much different from the fresh milkfish. All the thorns that are abundant in milkfish are no longer in the milkfish, pull the thorns and if touched they don't feel the thorns anymore. Milkfish products pull the thorns have the same meat texture as the milkfish that has thorns. The milkfish product is extracted in vacuum packaging so that there is no more air in the packaging that can damage the quality of the fish and sell for Rp. 60,000, - $/ \mathrm{kg}$.
The shredded milkfish product produced is good with the distinctive flavor of milkfish and the color of the shredded meat is quite interesting. Shredded milkfish products are packaged in vacuum plastic packaging and sold for Rp. $150,000,-/ \mathrm{kg}$.

The products of milkfish meatballs produced are quite good with the distinctive taste of milkfish and the color of fish meatballs which are quite interesting because they are whitish. When viewed from the appearance of milkfish meatballs, then at a glance it is no different from meat meatballs with distinctive color from meat; but later if it is consumed then there is a difference between the taste of the milkfish. Products of milkfish meatballs are traded in the form of vacuum plastic packaging; in packs per $1 \mathrm{~kg}$ of milkfish meatballs with the packaging price of $\mathrm{Rp}$. $70,000,-$

\section{ACKNOWLEDGMENT}

The highest gratitude and appreciation to the DP2M Ministry of Research, Technology and Higher Education which has funded the Regional Superior Product Development Program (PPPUD) Year II of 2019 Budget Year. Thank you also goes to Tegar Mandiri's UMKM partner group for their participation and good cooperation in implementing the PPPUD program.

\section{REFERENCES}

[1] Abriana, A. 2017. Teknologi Pengolahan dan Pengawetan Ikan (Technology for Processing and Preserving Fish). Publisher: CV SAH MEDIA Makassar.

[2] Afrianto, Eddy and Evi Liviawaty. 1989. Pengawetan dan Pengolahan Ikan (Preservation and Processing of Fish). Kanisius Publisher, Yogyakarta.

[3] Anonymous. 2010. Konsumsi Produk Perikanan di Sulawesi Selatan (Consumption of Fishery Products in South Sulawesi). Bappeda of South Sulawesi Province, Makassar.

[4] Indriastuti, Dewi Suprobowati, Dwi Hardaningtyas. 2018. Pengembangan dan Peningkatan Usaha Produk Olahan Bandeng Di Kecamatan Pakal Surabaya (Development and Improvement of Business of Processed Milkfish Products in Pakal District of Surabaya). AJIE - Asian Journal of Innovation and Entrepreneurship (e-ISSN: 24770574; p-ISSN: 2477-3824) Volume. 03, Issue. 01, January 2018.

[5] Ishak, Elly; H. Pakasi K; S. Berhimpon, CH Nanere L and Soenaryanto. 1985. Pengolahan Hasil Perikanan (Processing of Fisheries Products). Cooperation Agency for Eastern Indonesian State University.

[6] Kaet, L. and Hutapea, A. N. 2018. Analisis Finansial Usaha Abon Ikan pada Kelompok Pengolahan Ikan Pantura di Kelurahan Humusu C, Kecamatan Insana Utara, Kabupaten Timor Tengah Utara (Financial Analysis of Fish Abon in the Pantura Fish Processing Group in Humusu C Village, North Insana Subdistrict, North Central Timor Regency). Agrimor, 1 (04), pp. 82-83. doi: 10.32938\% ag.v1i04.112.

[7] Kobesi, P. and Hutapea, A. N. 2016. Prospek Pengembangan Usaha Abon Ikan di Kelurahan 
Humusu C, Kecamatan Insana Utara, Kabupaten Timor Tengah Utara (Prospects for Fish Abon Development in Humusu C Village, Insana Utara Subdistrict, North Central Timor District). Agrimor, 1 (02), pp. 21-23. doi: 10.32938/ ag.v1i02,100.

[8] Sulaiman. 2010. Kebijakan Pengelolaan Perikanan Berbasis Kearifan Lokal (The Fisheries Management Policy Based on Local Wisdom) KANUN No. 50 Edisi April 2010.

[9] Widarmanto, N. 2018. Kearifan Lokal Dalam Pengelolaan Sumberdaya Perikanan (Local Wisdom in Management of Fisheries Resources). Sabda Volume 13, Number 1, June 2018 ISSN 14107910 E-ISSN 2549-1628.

[10] Yanssen Moensaku, P. and Kune, SJ. 2016. Implementasi Marketing Mix Pada Pemasaran Abon Ikan Di Kelurahan Humusu C, Kecamatan Insana Utara Kabupaten Timor Tengah Utara (Studi Kasus Pada Kelompok Pengolahan Abon Ikan "Pantura") ('Implementation of Marketing Mix in Shredded Fish Marketing in Humusu C Village, North Insana District, North Central Timor Regency (Case Study of "Pantura" Abon Fish Processing Group))', PY Moensaku \& SJ Kune / Agrimor, 1 (4), pp. 78-81. Available at: https://media.neliti.com/media/publications/237712 -implementasi-marketing-mix-pada-pemasaracd3568ac.pdf. 